\title{
Changing the Message from 'Don't' to 'Do': Awareness-raising Strategies for Responsible Alcohol Use at a South African University
}

\author{
Vivian de Klerk \\ Rhodes University, South Africa \\ Email: V.deklerk@ru.ac.za \\ Charles Young \\ Rhodes University, South Africa
}

\begin{abstract}
This paper provides an overview of research on drinking behavior at a South African University. It describes new interventions, aimed to focus more positively on norms and the environment, and using Systemic Functional Grammar as a tool, provides a comparative linguistic analysis of the language used in 'public', alcohol-related texts before and after these interventions, in order to highlight the powerful effect of language in influencing attitudes to alcohol usage. After a brief discussion of these findings, some implications for practitioners are suggested
\end{abstract}

Index Terms - alcohol misuse, awareness-raising strategies, university students, SFG, appraisal

It is an oft-quoted and irrefutable fact that alcohol use is problematic at Universities all over the world (Johnson et al., 2006, p. 27, Presley et al., 1995), and that alcohol-related problems pose a very serious public health threat on campuses (e.g., Wechsler et al., 1994). While studies of usage patterns on South African campuses are very limited, there is no dearth of reliable research on such patterns in the USA (e.g. Wechsler et al., 1994, 1995, 1997; Wechsler \& Isaac, 1991), and in Europe, where alcohol misuse poses a huge public health problem (of all World Health Organization regions, Europe has the greatest proportion of alcohol related ill health and premature death) (Groves, 2010).

Most campuses struggle continuously with the negative consequences of heavy drinking, often viewed by students as a rite of passage, which predictably results in high-risk behaviors such as drunk-driving, assaults and aggressive behavior, unsafe sex, damage to property, as well as accidents and death (Eigen, 1991; Presley et al., 1995; Wechsler \& Isaac, 1991). Unlike some campuses, which avoid research on student alcohol use, for fear that what they might find could negatively impact the institution's reputation, during the past three years, some serious research has been conducted on drinking behavior at Rhodes University (Young \& de Klerk, 2009, Young \& Maysom, 2010), using the Alcohol Use Disorders Identification Test developed by the World Health Organisation. It showed that only about half of the students who completed the survey were drinking safely, another third were drinking hazardously, and the rest (18.4\%) were drinking at levels that are regarded as harmful, with many of them possibly dependent on alcohol.

The aim of this paper is to explore one of the underlying factors which might possibly be contributing to this sort of behaviour, namely, the effect of the type of language used to address this problem on campus. After a critical review of the efficacy of interventions against alcohol abuse on the campus during the past three years, the paper focuses on recent efforts by the Dean of Students Office to construct a more positive, norms-related approach to awareness-raising, focussing on students who drink moderately, or do not drink at all, rather than using the negative language commonly used to highlight the dangers of binge drinking (Johnson et al., 2006).

The paper then provides a comparative overview (using Systemic Functional Grammar as a tool) of the type of language used in alcohol-related texts before and after this change in strategy. This analysis reveals how powerful language can be in driving strategic change and ultimately influencing underlying attitudes to alcohol usage. The paper ends with some suggestions for practitioners.

\section{The NATURE of Recent Usage StUdies}

The methodologies employed in alcohol usage studies on campuses vary, but tend predominantly to rely on selfreported behavior (e.g. Thombs et al., 2003) which by its very nature is not very reliable (Harrell, 1997). There is a growing need to balance these studies with more 'scientific' objective measures of consumption patterns, such as that described by Johnson et al. (2006), who cites similar studies by Foss et al., (2003), Geller et al., (1991), and Voas et al. (2002). Such studies have typically focussed on self-assessed risk and breathalizer tests (Foss, Marchetti, \& Holladay, 2000; Foss et al., 2003).

Another branch of research into alcohol usage focuses on the efficacy of a range of interventions aimed to reduce consumption. An example of a successful intervention using a blend of social norms and environmental management is 
the University of Arizona where a 29\% decrease in heavy drinking is reported by Johannessen et al. (1999). Similar research by Johnson et al. (2006) provides a longitudinal evaluation over three years of a social norms program designed to reduce drunk driving and heavy drinking among students at San Diego State University. Based on voluntary, anonymous, and confidential interviews with 4,816 students (chosen at random, individually and in groups) on wellknown campus routes, followed by a breath sample, the research reports marked improvements, and recommends the efficacy of norm-linked interventions.

Most surveys and objective tests reveal that while there is evidence of heavy drinking among many participants, there are equally high numbers of students who drink moderately, or do not drink at all. Norm-related programs are based on the behaviors of this latter group, and try to use their behavior as a model around which new norms can be constructed, rather than using the negative imagery currently associated with the dangers of binge drinking (Johnson et al., 2006).

Research by Perkins and Berkowitz (1986) led the way in using such social norms as a basis for interventions around alcohol usage. They postulated the view that students typically over-estimate the use of alcohol by their peers, and as a consequence tend to increase their own consumption accordingly, in order to be one of the 'gang'. In a vicious cycle, the exaggerated perceptions tend to feed in to the construction of commonly accepted views (or myths) about how much students drink, and also inevitably contribute to an increase in the actual amounts that students feel pressured into drinking, in order to be 'normal' students. As Johannessen et al. (1999) stated "students become carriers of the misperception, regardless of their level of personal use" (p. 4). Perkins and Berkowitz emphasized the need to ascertain the difference between actual and perceived drinking norms, based on demographic characteristics such as race, gender and place of residence, and speculated that giving students accurate feedback about these norms could "effectively reduce drinking for heavier drinkers (who represent the minority of students) and support the safer behaviors of the moderate drinkers and non-drinkers (who represent the majority of students)" (Johannessen et al., 1999, p. 4).

According to several recent studies, social norms interventions can contribute to reducing alcohol-related harm in university contexts (Borsari \& Carey, 2003; Moreira, Smith, \& Foxcroft, 2009), both in terms of actual quantities, and in terms of attitudes. Reasons for the over-estimation are unclear, but they include the highly visible nature of antisocial drunken behavior (Young \& Maysom, 2010) - something that is especially relevant in a small-town context like Rhodes University - and a misconception that students who get drunk and behave badly personally believe that this is generally acceptable (without taking contextual factors into account).

Haines $(1992,1996)$ spearheaded the launching of such a program at Northern Illinois University, using social norms marketing techniques to counteract campus drinking misperceptions by providing reliable information about the actual behavior of the majority of students - whom their surveys had shown to be moderate, responsible drinkers. These marketing techniques are rooted in what he refers to as the PIE philosophy (Haines, 1998), with all messages in posters, adverts etc. being Positive, Inclusive and Empowering. Johannessen et al. (1999) describe such social norming as the repeated transmission and marketing (through a range of different media) of content which provides normative information aimed at replacing inaccurate misperceptions.

The actual marketing involves close collaboration with those individuals and organizations on campus and in the community who are concerned about the social ills of alcohol abuse, in order to agree on which strategies to adopt in order to achieve maximum public support for policy development and other proactive interventions. These stakeholders are obviously likely to differ widely, ranging from conservative academics and concerned residents of the town to students with liberal views and owners of bars eager to profit from alcohol sales, but it is important to acknowledge the complexity of their various agendas and work towards a common positive purpose. It is this positive, norms-based approach that informs the recent shift in intervention strategies at Rhodes University, and this shift and its consequences form the focus of the rest of the paper.

\section{THE LOCAL CONTEXT}

Rhodes is primarily a residential University, which occupies a very prominent position in the small town of Grahamstown, because it is the primary employer and because the annual influx of approximately 7000 students has a visible and very significant impact on the town, bringing with them huge buying power and a desire for entertainment. These factors contribute to the University's rather unenviable reputation as a "drinking university". The problem is regarded as serious, and there has been growing pressure from staff, the community and the police about student abuse of alcohol and its negative effects.

In the first awareness-raising campaign around alcohol usage launched by the Dean of Students office in 2007, the prevention strategies tended to be somewhat reactive rather than proactive in nature: a new Policy for the Responsible Use of Alcohol was passed by Senate and Council, bringing together a range of rules and regulations (which had been in place for many years) and incorporating new guidelines in relation to marketing and sponsorship, encouraging alternatives, increasing awareness, and providing support to addicted students. Other interventions included training and workshops for student leaders, an on-line usage survey and public campus discussions about the negative consequences of alcohol, particularly in relation to the annual Intervarsity sports competition, which had acquired a reputation for drunken, riotous behavior.

Two years later it was becoming clear that there had been little tangible or measurable success. While consecutive surveys over the two years did reveal a slight but statistically reliable 'improvement' (Young \& de Klerk, 2009, Young 
\& Maysom, 2010), in the big picture such results are probably negligible. For this reason, following the lead of Johannessen et al. (1999), in 2010 it was decided that using a social norming approach and positive environmental management might prove to be more effective, and a concerted effort was made to replace consistently negative, judgmental statements with more positive messages about the behavior of responsible students who could be rolemodels. The Rhodes Dean of Students Office adopted a new strategy focussed on addressing common misperceptions that most students drink heavily and harm themselves and others. The Dean of Students Office began to make an effort to counteract the perpetuation of such 'myths' (the norming aspect), while at the same time working at strategies to change the nature of campus events traditionally associated with unsafe drinking practices (e.g. orientation, intervarsity). The ultimate aim: to use more subtle, positive messages in order to convert heavy drinkers to moderate drinkers.

Among various strategies, a special effort was made to encourage Halls of Residence to enter into the Dean of Students alcohol-free challenge, the idea being to devise on-campus entertainment for large numbers of students and develop a different sense of what 'having fun' could mean for Rhodes students. In response to a claim in the local newspaper (Grocotts Mail) in early February that the prospect of a new student intake would inevitably mean more trouble, in the "love-hate" relationship between the town and Rhodes students, the Dean of Students sent an open letter $(4 / 2 / 10)$, emphasizing the many positive contributions that most students make during their time at the University (A rather jaded and very humorous piece followed in the student press, expressing amazed disbelief at the naivety of the Dean of Students). In a further effort to set a different tone during Orientation, student leaders postponed the traditional street party, and organized a range of alcohol-free events instead. They invited staff (who were requested to wear academic dress) and parents to a Jazz evening, the only event which did provide alcohol, thereby providing role models and setting the tone. Two weeks later, during the annual awareness-raising campaign around alcohol, a new event, the Dean of Students Variety Show, was staged, and 900 students filled the theatre for an enjoyable evening with staff and students performing a range of acts and creating good institutional and community memories in a proactive and positive way. The picture in the advertising poster depicted a happy, laughing female student having fun, unlike previous posters, which deliberately used shocking, provocative negative imagery.

During that week, a newly devised on-line alcohol usage survey was launched on the students' homepage, in which students were reminded that drinking is normal social practice, and were invited to ascertain where their drinking patterns fitted in, relative to their peers. Instant electronic feedback was provided to each respondent. In another intervention aimed to spread the word about responsible drinking in the community and promote cooperation with local alcohol purveyors, a 'publicans forum' was held to discuss common concerns, and following this, a joint open letter was sent to Grocotts Mail (text 7). Extensive press coverage about these events, both on and off campus, all assisted in slowly building a more positive attitude to the use of alcohol by students. The spontaneous, tongue-in-cheek, slang term "pulling a Viv" (an abbreviation of the Dean of Students' name, meaning 'having a night of relative abstinence from alcohol') appeared in at least three campus media during this time.

In order to test the effect of this change in strategy, an analysis of the type of language used in public, alcohol-related texts on campus before and after the change has been conducted, using the Appraisal system of Systemic Linguistics, which is described in the next section. The aim is to show how the deliberate decision to adopt a proactive, positive approach is actually manifested in language, and to provide some substance to the claim that this might lead to a change in underlying attitudes on campus.

\section{METHODOLOGY}

\section{A. Appraisal as an Analytical Tool}

One can use the Appraisal system (a recent development within Systemic Functional Linguistics (see Droga \& Humphrey, 2002; Macken-Horarik, 2003; Martin, 2000, 2003; Martin \& White, 2005; Martin \& Rose, 2003) to explore how interpersonal meanings are constructed in texts, both explicitly and implicitly, through the use of evaluative and attitudinal language. The Appraisal system has been effectively applied in a wide range of disciplines, such as drama (Martin, 2000), and the media (Martin, 2004), and several studies on the role of persuasive language have proven to be very useful in highlighting which words are particularly powerful in influencing attitudes (Adendorff \& de Klerk, 2005; Mackin-Horarick, 2003; Marshall, Adendorff, \& de Klerk, 2009; Myers, 1989). Appraisal offers a powerful analytical tool for the purposes of uncovering attitudes in texts (spoken or written) and showing how they affect attitudes and create solidarity by negotiating their positions and aligning listeners and readers.

Briefly, Systemic Functional Linguistics classifies language in use into three broad metafunctions: the experiential, the interpersonal and the textual. The experiential metafunction is concerned with the way we use language to try to build a logical and comprehensive picture of the way we experience the world, and its impact on us. The interpersonal metafunction focuses on language use when people interact, negotiate and establish relationships; and the textual metafunction is concerned with the logical organization of language that enables texts to function coherently as a whole. All three functions are interlinked in any text, but it is most particularly the interpersonal metafunction that concerns us here, because it is a tool designed to explore the ways in which language is used strategically to communicate attitudes, evaluations, feelings, judgements of others and appreciation of entities, as part of a process of aligning an audience and creating a 'community of feeling' (Droga \& Humphrey, 2002; Martin \& White, 2005). 
In particular, this paper concerns itself with the expression of attitude: 'the resources used to make either a positive or negative evaluation of phenomena' (Droga \& Humphrey, 2002, p. 75). Attitudinal evaluations, are classified according to the expression of one's feelings or emotions (Affect), a normative or moral judgement of peoples' behavior (Judgement) and the evaluation of objects, artefacts or situations (Appreciation).

Within the subsection of Affect, feelings (either positive or negative) are categorized according to Happiness, Security and Satisfaction, as exemplified in words such as cheerful, confident, impressed (positive affect) and hate, anxious, bored (negative affect) (Martin, 2000). Examples of words expressing Judgement are: 1ucky/tragic (normality), clever/slow (capacity), brave/cowardly (tenacity), honest/deceitful (veracity) and moral/evil (propriety) (Martin, 2000). Other aspects of the system, including Appreciation, Graduation and Engagement, are not of immediate relevance to this discussion, which focuses primarily on Attitude.

\section{B. Data}

Two sets of texts (texts 1-5) were selected for analysis and comparison in term of the expression of attitude, using the Appraisal framework. The first set comprised key public alcohol-related texts issued between 2008 and 2009, before the decision had been made to develop a positive norm-based strategy. The second public texts (texts 6 and 7) were issued in 2010, after the norms-based approach had begun. In the first set, Text 1is the University's Responsible Use of Alcohol Policy (http://www.ru.ac.za); Text 2 is the editorial (5/3/08) of one of the student newspapers, "The Oppidan Press", expressing students' views on what was perceived as a 'clamp-down' by the Dean of Students on the use of alcohol by students. Text 3 is the response of the Dean of Students to these views, published a month later in the local newspaper, Grocotts Mail; Text 4 is a collection of angry letters to the Dean of Students from members of the public following intervarsity weekend (September 2009), during which the loud and unruly behavior of drunk students caused a public outcry; and Text 5 is a public statement on campus made by the Dean of Students on the intranet, immediately following this outcry. The second set comprises Text 6, a letter to the editor of the Grocotts Mail (4/2/10) from Rhodes' Dean of Students, emphasizing the many positive contributions that most students make during their time at the University, and Text 7 , another letter to the editor (05/10) from the 'publicans forum', commenting on the efforts of town and gown to respond to students' use of alcohol.

The tables below reflect the total number of evaluative terms which express attitude in each text. The percentages in the right-hand column of each table represent the proportion of negative terms in relation to the number of positive terms in that particular text.

\section{RESUlTS}


EXPRESSIONS OF ATTITUDE IN ALCOHOL-RELATED TEXTS

SET 1: TEXTS WRITTEN BEFORE THE INTRODUCTION OF A POSITIVE NORM-BASED STRATEGY

\begin{tabular}{|c|c|c|c|}
\hline Text 1: & & Alcohol Policy & $67 \%$ negative \\
\hline & $\begin{array}{l}\text { Attitude happiness, } \\
\text { security satisfaction }\end{array}$ & $\begin{array}{l}\text { risk (8); violence, injuries, death, harm (2), exacerbated, difficulties, toxicity, } \\
\text { problem(s) (4), negative, avoid, } \\
\text { enjoy, safe(ty) (4), pleasant, health(y) (3), well-being }\end{array}$ & $\begin{array}{l}\text { Negative: } 22 \\
\text { Positive: } 10\end{array}$ \\
\hline & $\begin{array}{lr}\text { Judgement } & \text { Capacity } \\
\text { Tenacity } & \text { Normality } \\
\text { Propriety } & \end{array}$ & $\begin{array}{l}\text { restrict(ed) (3), supervision, limit (5), prohibit(ed) (2), forbid(den) (2), control } \\
\text { (4), permit / permission (10), allow, monitor, approved / approval (3), discipline } \\
\text { (3), authorities, abstinence, addiction, dependency, heavy (2), excessive (4) } \\
\text { support (10), encourage (9), assist, help (2), care, enlightened, mature, normal, } \\
\text { balanced, moderate, responsible (5) }\end{array}$ & $\begin{array}{l}\text { Negative: } 45 \\
\text { Positive: } 33\end{array}$ \\
\hline & $\begin{array}{l}\text { Appreciation } \\
\text { Reaction Valuation }\end{array}$ & $\begin{array}{l}\text { unacceptable, complain, dissatisfaction, noise, rowdy, drunken, intoxicated (5), } \\
\text { alcohol- / glass free (6), non-alcoholic (4) }\end{array}$ & $\begin{array}{l}\text { Negative: } 21 \\
\text { Positive: } 0\end{array}$ \\
\hline \multirow[t]{4}{*}{ Text 2: } & & Oppidan Press Editorial 5/2/08. & $85 \%$ negative \\
\hline & $\begin{array}{l}\text { Attitude happiness, } \\
\text { security satisfaction }\end{array}$ & $\begin{array}{l}\text { rapes, man-handling, crack-down, clamped down, herded, rough, worrying (2), } \\
\text { self-conscious, harsh, spoil } \\
\text { fun, safe, commendable }\end{array}$ & $\begin{array}{l}\text { Negative: } 11 \\
\text { Positive: } 3\end{array}$ \\
\hline & $\begin{array}{lr}\text { Judgement } & \text { Capacity } \\
\text { Tenacity } & \text { Normality } \\
\text { Propriety } & \end{array}$ & $\begin{array}{l}\text { got to stop, sweeping generalizations, wouldn't dare, regulations, supposed to; } \\
\text { dragon, breathing down your neck, mistakes (2), wrong, learn (2), drinking } \\
\text { habits, misuse (2), dependant } \\
\text { responsible, mature /-ity (2) }\end{array}$ & $\begin{array}{l}\text { Negative: } 16 \\
\text { Positive: } 3\end{array}$ \\
\hline & $\begin{array}{l}\text { Appreciation } \\
\text { Reaction Valuation }\end{array}$ & chill out (2), severe, unforgiving, alienate, badmouthing, doubt, not making light & $\begin{array}{l}\text { Negative: } 8 \\
\text { Positive: } 0 \\
\end{array}$ \\
\hline \multirow[t]{4}{*}{ Text 3: } & & Response from the Dean of Students. & $69 \%$ negative \\
\hline & $\begin{array}{l}\text { Attitude happiness, } \\
\text { security satisfaction }\end{array}$ & $\begin{array}{l}\text { violence, rape , alcohol(ism) (3), scary, poisoning, risk (3), harmful, rushed to } \\
\text { hospital, life-threatening, crisis, accident, death, issue alert, poisoning, } \\
\text { marvellous, fun, enjoy, safety (2), wellbeing }\end{array}$ & $\begin{array}{l}\text { Negative: } 18 \\
\text { Positive: } 6\end{array}$ \\
\hline & $\begin{array}{lr}\text { Judgement } & \text { Capacity } \\
\text { Tenacity } & \text { Normality } \\
\text { Propriety } & \\
\end{array}$ & $\begin{array}{l}\text { expose , stop (drinking), over-reacting, clamping down, disciplinary, police, } \\
\text { dependent, addict, alternatives, drunk, responsible /ity (4), } \\
\text { encourage, promote, support }\end{array}$ & $\begin{array}{l}\text { Negative: } 10 \\
\text { Positive: } 7\end{array}$ \\
\hline & $\begin{array}{l}\text { Appreciation } \\
\text { Reaction Valuation }\end{array}$ & $\begin{array}{l}\text { unenviable reputation, complain, unwanted pregnancies, serious injuries, binge } \\
\text { drinking } \\
\text { care (2) }\end{array}$ & $\begin{array}{l}\text { Negative: } 5 \\
\text { Positive: } 2\end{array}$ \\
\hline \multirow[t]{4}{*}{ Text 4: } & & Public complaints about Intervarsity & $86 \%$ negative \\
\hline & $\begin{array}{l}\text { Attitude happiness, } \\
\text { security satisfaction }\end{array}$ & $\begin{array}{l}\text { problem (3), trouble(s), concerned, littered (2), strewn (2), fierce, disapproval, } \\
\text { fights (3), mob, bad(ly) (5), broken bottles/glass (9), unpleasant, violent (4), } \\
\text { hooligan(ism) (3), vandalism, "piss up", jorl, confrontations, hurling, trashing, } \\
\text { vomit, urine, harassment, sexist slurs (4), insults, racism (7), abuse (3), grabbed, } \\
\text { pushed, punched, accosted, vicious, throwing, shouting, dragged, death, unruly, } \\
\text { uncontrolled, vulnerable, out of hand, not coping, endanger, sleep deprivation, } \\
\text { crisis, doomed, intimidating, threatening, victims, ill } \\
\text { good sense, better nature, good, safety, excellence }\end{array}$ & $\begin{array}{l}\text { Negative: } 64 \\
\text { Positive: } 5\end{array}$ \\
\hline & $\begin{array}{lr}\text { Judgement } & \text { Capacity } \\
\text { Tenacity } & \text { Normality } \\
\text { Propriety } & \end{array}$ & $\begin{array}{l}\text { lack of respect, ordinary citizens, absolute fiasco, insufficient security, } \\
\text { drunk(enness) (20), disciplinary action, perpetrators, extraordinary, nonsense, } \\
\text { party animals, sanction, bann(ed) (2), control (3), corporal punishment, rectify, } \\
\text { cancellation (2), custodians, monitors, marshals, take action, not enough, } \\
\text { misbehavior, hard core, terminated, unacceptable, non negotiable, despicable, } \\
\text { debauchery, unruly, bingeing, spoiled brats, loutish, public, visibly, stupidity, } \\
\text { don't allow, harsh, tackled head on, unnecessary, mess, uncalled for, stop, } \\
\text { cannot behave, close down, beyond "disorderly, turned a blind eye, firm stand, } \\
\text { indulging, adolescent, idle threats, lack, enforcement, discipline (3), flawed, } \\
\text { stupid, apology, prissy, grump. } \\
\text { face-saving, moderate, civil (2) sober, dignity (3), rights, seemly, role models, } \\
\text { religious values, tolerant (4), excused, reasonable, reputation, responsible, } \\
\text { proud, law abiding, standards, fair }\end{array}$ & $\begin{array}{l}\text { Negative: } 84 \\
\text { Positive: } 24\end{array}$ \\
\hline & $\begin{array}{l}\text { Appreciation } \\
\text { Reaction Valuation }\end{array}$ & $\begin{array}{l}\text { loud thumping music (4), shocking (2), offensive (3), vulgar }(2) \text {, } \\
\text { unfortunate(ly), frankly embarrassing (3), anger (2), disgust (2), } \\
\text { disappointment, criticism (2), despicable (2), ashamed (3), terribly saddened (2), } \\
\text { hang my head, deeply uncomfortable, deeply troubled, deplore, disowned, } \\
\text { hatred, appalled (3), horrific, bloody, outrageous, appreciate }\end{array}$ & $\begin{array}{l}\text { Negative: } 41 \\
\text { Positive: } 1\end{array}$ \\
\hline \multirow[t]{4}{*}{ Text 5: } & & Message from the Dean of Students & $82 \%$ negative \\
\hline & $\begin{array}{l}\text { Attitude happiness, } \\
\text { security satisfaction }\end{array}$ & Unfortunately, violators (3), hate speech, "rape speech" & $\begin{array}{l}\text { Negative: } 6 \\
\text { Positive: } 0\end{array}$ \\
\hline & $\begin{array}{lr}\text { Judgement } & \text { Capacity } \\
\text { Tenacity } & \text { Normality } \\
\text { Propriety } & \\
\end{array}$ & $\begin{array}{l}\text { ban, not acceptable, drunken, loutish, very visible and vocal behavior, proudly } \\
\text { displayed, sober, dignity (2) }\end{array}$ & $\begin{array}{l}\text { Negative:5 } \\
\text { Positive: } 4\end{array}$ \\
\hline & $\begin{array}{l}\text { Appreciation } \\
\text { Reaction Valuation }\end{array}$ & Offensive (2), shocking, appalling, outrage, complainant, disturbing & $\begin{array}{l}\text { Negative: } 7 \\
\text { Positive:0 }\end{array}$ \\
\hline
\end{tabular}




\begin{tabular}{|c|c|c|c|}
\hline \multicolumn{4}{|c|}{ SET TWO: TEXTS WRITTEN AFTER THE INTRODUCTION OF A POSITIVE NORM-BASED STRATEGY } \\
\hline Text 6: & & Public letter to the press & $27 \%$ negative \\
\hline & $\begin{array}{l}\text { Attitude happiness, } \\
\text { security satisfaction }\end{array}$ & $\begin{array}{l}\text { sadly, abuse, antisocial, sex-crimes, unpleasant } \\
\text { perfect, good, well-rounded, community engagement (2), rights (3), } \\
\text { excellence, relaxation, entertainment, positive, love, party, music, } \\
\text { enjoy, hi-jinks, benefit, humour, exuberance }\end{array}$ & $\begin{array}{l}\text { Negative: } 5 \\
\text { Positive: } 20\end{array}$ \\
\hline & $\begin{array}{l}\text { Judgement Capacity } \\
\text { Tenacity Normality } \\
\text { Propriety }\end{array}$ & $\begin{array}{l}\text { infringe, disregard, disciplinary, antisocial, yobbish, disgrace, waste, } \\
\text { lost, judge, take action } \\
\text { challenge (2), try, gently, firmly, encourage (2), hard work, confident, } \\
\text { intelligent, sensitive, eager, keen, socially aware, compassionate, } \\
\text { concerned, adults, responsibility (3), tolerate, volunteers, tirelessly, } \\
\text { talent, competition (2), debates, activities, leaders, considerate (3), } \\
\text { proud (2), accountable }\end{array}$ & $\begin{array}{l}\text { Negative: } 10 \\
\text { Positive: } 35\end{array}$ \\
\hline & $\begin{array}{l}\text { Appreciation } \\
\text { Reaction Valuation }\end{array}$ & $\begin{array}{l}\text { prejudices (2), problem, shock, provoke, warned (2) } \\
\text { amazing, exciting, love, acknowledge, values }\end{array}$ & $\begin{array}{l}\text { Negative: } 7 \\
\text { Positive: } 5\end{array}$ \\
\hline \multirow[t]{4}{*}{ Text 7: } & & Open letter from Publicans' Forum & $22 \%$ negative \\
\hline & $\begin{array}{l}\text { Attitude happiness, } \\
\text { security satisfaction }\end{array}$ & $\begin{array}{l}\text { public, loud } \\
\text { alcohol-free events, fun, enjoyment, acceptable, sociable, partners (2) }\end{array}$ & $\begin{array}{l}\text { Negative: } 2 \\
\text { Positive: } 7\end{array}$ \\
\hline & $\begin{array}{l}\text { Judgement Capacity } \\
\text { Tenacity Normality } \\
\text { Propriety }\end{array}$ & $\begin{array}{l}\text { drunken exploits, intoxicated, heavy drinkers, antisocial } \\
\text { encourage (2), responsible / -ity (4), norms, seriously, effort, } \\
\text { proactively (2), initiated, challenging, cooperate, promoting, continue, } \\
\text { endeavour, well-balanced }\end{array}$ & $\begin{array}{l}\text { Negative: } 4 \\
\text { Positive: } 18\end{array}$ \\
\hline & $\begin{array}{l}\text { Appreciation } \\
\text { Reaction Valuation } \\
\end{array}$ & $\begin{array}{l}\text { Complaints (2) } \\
\text { misperceptions, positively, pride }\end{array}$ & $\begin{array}{l}\text { Negative: } 2 \\
\text { Positive: } 3\end{array}$ \\
\hline
\end{tabular}

\section{DISCUSSION}

The analysis of the first text set shows a preponderance of negative lexical items in all categories in all texts, reaching a climax in the angry letters from the public. In these texts, the percentages in the right-hand column show a significantly higher proportion of negative terms in relation to the number of positive terms in each text, reflecting a steadily growing clamour of outrage and a sense of overwhelming condemnation on the part of the University (in three of them, over $80 \%$ of all evaluative terms are strongly negative). In contrast, texts 6 and 7 present a very different picture, with only $27 \%$ and $22 \%$ of negative terms respectively. These two key 'public' texts demonstrate a major change in lexical choices, and a clear shift to a more positive message (with $76 \%$ positive evaluative terms overall).

The powerful, almost draconian authoritative tone of disapproval and contempt evident in the first set of texts has probably not assisted well-meaning efforts to reduce harmful drinking. Results of the Rhodes campus on-line surveys over two years confirm this (Young and de Klerk 2009), and evidence that the problem of alcohol misuse appears to be growing has made it clear that it is not enough simply to educate and warn students about alcohol and its effects and complain about the social ills and reputational damage linked to intoxication. The traditional knowledge approach has a limited effect, and this has been shown to be the case on other campuses as well (Gonzales, 1991; Goodstadt, 1986; Oblander, 1984), where similar programs show little overall benefit in reducing harm and risk. (Similarly, an abstinence-only message fails to work with older adolescents and those who have already started drinking (Flynn et al., 1991; Kraft, 1988).

\section{IMPLiCATIONS FOR PRACTICE}

It will be important to monitor the effect of the shift in strategy which has been outlined above, over time. An online alcohol-usage survey is conducted annually on campus, and this will be one means of measuring the outcomes. Regardless of whether patterns change for the better, results of the most recent online survey of March 2010 confirm the trend reported in previous research (Johannessen et al. 1996; Perkins and Berkowitz, 1986) that students over-estimate the drinking behaviour of their peers, and that this in turn may be influencing their own consumption patterns. The survey asked respondents to estimate their own drinking and the drinking of a typical same-sex peer along three key factors: the frequency of drinking, the amount of alcohol consumed on a typical day when drinking and the frequency of binge drinking defined as the consumption of six or more standard alcoholic drinks on any single occasion. Of the approximately 7000 students registered at Rhodes, 2179 completed the survey (1236 women and 943 men) - roughly $31 \%$ of the entire student body. Statistics gathered from this survey revealed that students were indeed overestimating the drinking habits of their peers. For example, $50.6 \%$ of students overestimate the frequency of alcohol consumption, $44.3 \%$ the amount that is consumed on a typical drinking occasion and $54.4 \%$ the frequency of binge drinking. The differences between the actual and estimated means are statistically significant $(p=0.001)$ for each of the three dependent sample t-tests. Using the median score as the best indication of what is typical, then the typical student has a drink containing alcohol two to four times every four week. Even if this is rounded up to once a week, it is still less than the estimated two to three times a week. On these drinking occasions, the typical student consumes three or four drinks, not the five or six that is typically estimated.

This data is being used to construct a different style of messaging around alcohol, which is positive, and is focussed on the 'good' responsible norms of the majority of students, supported by reliable information and facts from credible 
data sources. A series of posters (with familiar, repeated design elements to enhance recognition) are being produced which will display statements such as "Most Rhodes students have two or fewer drinks on a night out" and "Most Rhodes students drink responsibly - only $11 \%$ drink harmfully". Drink equivalency information will also be provided, alongside the recognizable logo of the Dean of Students office. The key content of the posters will be on how often typical students drink and how many drinks they consume on a typical drinking occasions. The posters aim to represent a diversity of students having fun in realistic, familiar settings, so that the various sub-cultures (black, white, male, female etc.) will associate themselves with at least one of the images being used. Particular care will be taken to use images of students who are known to be moderate drinkers. The overall desired effect is to create a clear, simple message which avoids negative terms (e.g. 'binge', 'anti', 'abuse' or 'dangers') or moralistic judgements about 'bad' behavior.

In this way, it may be possible to build on the platform of a positive, tolerant approach to responsible drinking, and address common misperceptions regarding alcohol use by most students in a non-threatening manner. By making an effort to avoid linking alcohol use in any way with morality, and rather to focus rather on health and safety (following Johannessen et al., 1999), the thrust will be optimistic, with a message which aims to engage students as intellectuals, with material that is intelligent, accurate, familiar and non-judgemental. Shifting the paradigm from fear-based alcohol prevention to the social norms approach with a consistent, non-defensive message aims to encourage stakeholders to adopt a new perspective and outlook regarding alcohol prevention.

In order to ensure a buy-in from the wider community, these changes have been discussed in University committees and forums, supported by wardens and other senior staff (including the University Senate), and other key stakeholders including the local police and bar owners. It has also been publicly endorsed by the Students Representative Council. The focus in nurturing stakeholders is on empowerment, persuasion, and partnership. The next stage in the strategy will involve a review of policies and protocols linked to alcohol, alongside a review of materials distributed to students about these policies and about alcohol in general, in order to reveal the existence of possible mixed messages. As each cohort of students moves through the University, the permanent staff need to be relied on to convey the same, consistent and positive message about student norms, and these norms need to be tested regularly to ensure they remain credible and research-based.

In addition to measuring change statistically with a follow-up on-line survey, it will be useful to measure change linguistically as well: in a year's time, after the poster campaign has run its course, during a period of one month, all alcohol-related messages displayed off-campus, both on public notice boards or in local newspapers and other media will be collected for analysis (including bar promotions and local press coverage of alcohol-related incidents), to ascertain whether perceptions have changed.

\section{CONCLUDING REMARKS}

The change in strategies around alcohol usage on campus has been based on the premise that negative thinking breeds negative thinking, and that, unwittingly, officials at the university, fuelled by the negative attitudes of complaining members of the public, have begun to 'nag'. The textual analysis, comparing pre- and post-strategy public texts, has provided useful evidence that the mood of the first set of texts is indeed one of strong disapproval and harsh judgement and condemnation. This has, in all likelihood, drowned out the underlying intention of these texts: to remind students that responsible drinking is good and that the university will provide care and support. It is indeed feasible that the recipients (or targets) of these messages have become a little defensive over time, and it is even possible that some students might have deliberately started to drink more as a result. It will be interesting to monitor the effect of the new strategy described in this paper, represented by the much more positive tone of the second set of texts, and echoed in the poster campaign which will shortly commence. It is hoped that new drinking norms will slowly be established via these channels.

Of course, in addition to the sorts of written texts which have been analysed in this paper, there are also many public verbal messages to students, and until recently, they have also shared the strongly negative and condemnatory tone of texts 1 to 5: both the Vice Chancellor and Dean of Students vigorously stress the dangers of alcohol abuse when they address all first-year students in the first week at Rhodes; in the residences later in that week, workshops are run by senior students, and one of the topics is substance 'abuse'. A week later, the first awareness-raising initiative coordinated by the office of the Dean of Students has always been "Anti-alcohol Abuse Week" (the words "anti" and "abuse" express the same disapproving attitude which predominates in the foregoing texts). It will also be important to ensure parallel shifts in the tone of such verbal messages and activities in future.

This paper used linguistic analysis to test the effect of a deliberate change in strategy, and to show how a proactive, positive approach is actually manifested in the language of public texts about alcohol. The paper argues that genuine culture change, in terms of counteracting the negative effects of alcohol usage in a permanent and effective way, will indeed be effected by consistent positive language use of this kind, and will also depend on a long-term commitment from key stakeholders to adopt a consistent, positive approach, emphasizing the moderate behaviors of the majority of students, and fully endorsed at all levels of the University, especially the most senior. Johannessen et al. (1999) tracked student opinion about alcohol-free events on their campus, and reported a statistically significant increase in student 
support for such events over a three-year period. Time will tell whether Rhodes students feel the same, and ongoing research will have to monitor the long-term efficacy of a norms-based positive approach to alcohol consumption.

\section{REFERENCES}

[1] Adendorff, R., \& de Klerk, V. (2005). The role of APPRAISAL resources in constructing a community response to AIDS. Linguistics and the Human Sciences, 1(3), 489-513.

[2] Droga, L., \& Humphrey, S. (2002). Getting started with Functional Grammar. Berry, New South Wales: Target Texts.

[3] Eigen, L. D. (1991). Alcohol practices, policies, and potentials of American Colleges and Universities. White paper. Rockville, MD: Office for Substance Abuse Prevention.

[4] Flynn, C. A., \& Brown, W. E. (1991). The effects of a mandatory alcohol education program on college student problem drinkers. Journal of Alcohol and Drug Education, 37, 15-24.

[5] Foss, R., Diekman, S., Goodwin, A., \& Bartley, C. (2003). Enhancing a norms program to reduce high-risk drinking among first year students. Chapel Hill: University of North Carolina, U.S. Department of Education.

[6] Foss, R. D., Marchetti, L. J., \& Holladay, K. A. (2000). Development and evaluation of a comprehensive program to reduce drinking and impaired driving among college students. DOTHS 809 396. Washington, DC: National Highway Traffic Safety Administration.

[7] Goodstadt, M. S. (1986). School-based drug education in North America: What is wrong? What can be done? Journal of School Health, 56(7), 278-281.

[8] Gonzales, G. M. (1991). Five-year changes in alcohol knowledge, consumption and problems among students exposed to a campus-wide alcohol awareness program and a rise in the legal drinking age. Journal of Alcohol and Drug Education, 37, 8191.

[9] Geller, E. S., Kalsher, M. J., \& Clarke, S.W. (1991). Beer vs mixed drink consumption at fraternity parties: A time and place for low-alcohol alternatives. Journal of Studies on Alcohol, 52(3), 197-204.

[10] Groves, T. (2010). Preventing alcohol related harm to health. British Medical Journal, 340, 372-374.

[11] Harrell, A. V. (1997). The validity of self-reported drug use data: The accuracy of responses on confidential self-administered answered sheets. NIDA Research Monograph, 167, 37-58.

[12] Haines, M. P. (1996). A social norms approach to preventing binge drinking at colleges and universities. Newton, MA: The Higher Education Center for Alcohol and Other Drug Prevention, Education Development Center, Inc.

[13] Haines, M. (1992). Using media to prevent alcohol abuse: a tested model. Workshop presented at the Sixth Annual FIPSE Grantee Meeting, Washington, D.C. October 23-26.

[14] Haines, M. (1998). Social norms a wellness model for health promotion in higher education. Wellness Management, 14(4), 1-8.

[15] Johannessen, K., Collins, C., Mills-Novoa, B., \& Glider, P. (1999). A campus case study in Implementing social norms and environmental management approaches. Campus Health Service, University of Arizona Tucson, AZ 85721.

[16] Johnson, M., Lange, J., Voas, R. B., Clapp, J., Lauer, E., \& Snowden, C. (2006) .The sidewalk survey: A field methodology to measure late-night college drinking. Evaluation Review, 30(1), 27-43.

[17] Kraft, D. P. (1988). The prevention and treatment of alcohol problems on a college campus. Journal of Alcohol and Drug Education, 34(1), 37-51.

[18] Mackin-Horarik, M. (2003). APPRAISAL and the special instructiveness of narrative. Text, 23(2), 285-312.

[19] Marshall, C., Adendorff, R., \& de Klerk,V. (2009). The role of APPRAISAL in the NRF Rating System: an analysis of Judgement and Appreciation in peer reviewers' reports. Southern African Linguistics and Applied Language Studies 27(4), 391-412.

[20] Martin, J. R. (2000). Beyond exchange: APPRAISAL systems in English. In S. Hunston \& G. Thomson (eds), Evaluation in texts: authorial stance and the construction of discourse (pp.142-175). Oxford: Oxford University Press.

[21] Martin, J. R., \& White, P. R. R. (2005). The language of evaluation: Appraisal in English. Basingstoke / New York: Palgrave Macmillan.

[22] Martin, J. R. (2003). Introduction. Text, 23(2), 171-181.

[23] Martin, J. R. (2004). Mourning: How we get aligned. Discourse \& Society, 15(2/3), 321-344.

[24] Martin, J. R., \& Rose, D. (2003). Working with Discourse: Meaning Beyond the Clause, London: Continuum.

[25] Myers, G. (1989). The pragmatics of politeness in scientific articles. Applied Linguistics, 10(1), 1-30.

[26] Oblander, F. W. (1984). Effective alcohol education strategies. ACU-1 Bulletin, 52, 17-25.

[27] Perkins, H. W., \& Berkowitz, A. D. (1986). Perceiving the community norms of alcohol use among students: Some research implications. The International Journal of the Addictions, 21 (9), 44-50.

[28] Presley, C. A., Meilman, P.W., \& Lyerla, R. (1995). Alcohol on American college campuses: use, consequences, and perceptions of the campus environment. Vol. 2. Carbondale, IL: CORE Institute Student Health Programs, Southern Illinois University at Carbondale.

[29] Thombs, D. L., Olds, R. S., \& Snyder, B. M. (2003). Field assessment of BAC data to study late night college drinking. Journal of Studies on Alcohol, 64(3), 322-30.

[30] Voas, R. B., Tippetts, A., Johnson, M. B., Lange, J. E., \& Baker, J. (2002). Operation safe crossing: using science within a community intervention. Addiction, 97(9), 1205-14.

[31] Wechsler, H., Davenport, A., Dowdall, G., Moeykens, B., \& Castillo, S. (1994). Health and behavioural consequences of binge drinking in college: A national survey of students at 140 campuses. Journal of the American Medical Association, 272(21), 1672-77.

[32] Wechsler, H., Dowdall, G. W., Davenport, A., \& Rimm, E. B. (1995). A gender-specific measure of binge drinking among college students. American Journal of Public Health, 85(7), 982-85.

[33] Wechsler, H., Fulop M., Padila, A., Lee, H., \& Patrick, K. (1997). Heavy episodic drinking among college students: A comparison of California with other states. American Journal of College Health, 45, 273-77. 
[34] Wechsler, H., \& Isaac, N. (1991). Alcohol and the College Freshman: "Binge" Drinking and Associated Problems. Washington, DC: AAA Foundation for Traffic Safety.

[35] Young, C., \& de Klerk, V. (2009). Patterns of alcohol use on a South African university campus: The findings of two annual drinking surveys. African Journal of Drug \& Alcohol Studies 7, 101-112.

[36] Young, C., \& Maysom, T. (2010). The Alcohol Use Disorders Identification Scale (AUDIT) normative scores for a multiracial sample of Rhodes University residence students. Journal of Child and Adolescent Mental Health, 22(1), 15-23.

Vivian de Klerk is currently the Dean of Students at Rhodes University. She obtained her BA (Hons) and MA degrees in Linguistics, cum laude from Rhodes University, South Africa and a PhD from UCT, as well as completing an HDE degree from Unisa. She was Professor and Head of the Department of English Language and Linguistics at Rhodes University from 1991 to 2006 , and during that time she was also Deputy Dean of Humanities for 6 years and University Public Orator for 4 years. On a national level, she served as President of the Linguistics Society of Southern Africa from 1995-2002, and also served on the South African Geographical Names Council, the boards of the South African Academy of Science and the English National Language Body, and chaired the Provincial Language Council for Eastern Cape Province from 1998 - 2003. Her research interests include slang and expletives, language shift and varieties of English, especially Black South African English She has published over 90 peer-reviewed journal articles and two scholarly books, and was awarded the Rhodes Vice Chancellor's Senior Research Award in 2004, and is a rated South African researcher. In 2007 she became the Dean of Students at Rhodes University.

Charles Young is a counselling psychologist who has trained and is registered in both South Africa and the United Kingdom. After completing his MA in Counselling Psychology (cum laude) at the University of Natal in Pietermaritzburg in 2000, he worked at Addenbrooke's Hospital in Cambridge for five years. While working in the UK, he completed a doctorate in Counselling Psychology at the University of Essex in 2006.

Dr Young returned to South Africa as Head of the Rhodes University Counselling Centre in 2007, and has since moved to the Rhodes University Psychology Department as a Senior Lecturer and academic coordinator of the clinical and counselling psychology professional training programmes. He is a member of the British Psychological Society as a chartered psychologist (C. Psychol), the Health Professions Council of the UK (HPC-UK) and the Health Professions Council of South Africa (HPCSA). His research interest include issues of public mental health. 